\title{
Accommodating the Interest of Local Community in Resolving Conflicts: A Case in Bentayan's Wildlife Area, South Sumatra, Indonesia
}

\author{
Didi Tahyudin ${ }^{1}$, Ridha Taqwa ${ }^{1}$, Dadang H. P. ${ }^{1}$ \& Alfitri $^{1}$ \\ ${ }^{1}$ University of Sriwijaya, Palembang, Indonesia \\ Correspondence: Alfitri, University of Sriwijaya, Palembang, Indonesia. E-mail: al_fitri2002@yahoo.com
}

Received: October 8, 2014 Accepted: November 6, $2014 \quad$ Online Published: November 18, 2014

doi:10.5539/sar.v4n1p41 URL: http://dx.doi.org/10.5539/sar.v4n1p41

\begin{abstract}
The developments of forest conservation Wildlife (SM) in Bentayan as flora and fauna ecology has created a conflict within the society and has negatively affected the wellbeing of the community in the area. The communities have used a lot of natural resources for their life. A development of Bentayan's Wildlife Centre has been opposed by the community as the usage of various natural resources have been restricted after the development of the wildlife centre started. In order to solve the conflicts, many strategies have been employed. However, the expected outcome has not yet been achieved. Therefore, the current study provides a conflict resolution model approach to accommodate the interests of all parties, both society and government through the Natural Resources Conservation Center. The model was developed from narrative data that was collected through series of dialogues and negotiation process with both parties (community and agency/Centre) involving stakeholders and community members. This proposed model can be used as a framework for managing forestry and wildlife centre.
\end{abstract}

Keywords: conflict management, community, wildlife, development, agriculture, rural society

\section{Introduction}

\subsection{Background}

The forest area has a very strategic role either for ecological stability, economic purposes, social interests or cultural preservation. The forest economy functions as production sources of wood, rattan, mushrooms, food, traditional medicines, fruits, tourist places, firewood, animal feed, and other economic interests. In addition, the forest serves as a place for livelihood for people to secure the basic necessities such as water supply from spring water, prevent soil erosion and ensure soil fertility setting. Forests produces oxygen by absorbing carbon dioxide and potentially harmful gasses, such as sulfur, and in turn, replenish the atmosphere by recycling these gasses into oxygen. Ecological forest functions as the main counterweight to keep the integrity and stability of the world's ecosystems. This is stated in the Declaration of Rio de Janeiro by the UN: function of forest resources to meet social and economic needs of society, the balance of ecological, cultural and spiritual generation in the future. Past empirical study revealed that economic developments have a strong connection with societal wellbeing (Jalaluddin, Abdul Razaq, Mohd Mahzan, \& Alfitri, 2014).

Indonesia has huge areas of forest that is very influential on the equilibrium climate both regionally and globally. Due to the extensive physical development over the years, many forests were destroyed. The rate of deforestation in Indonesia for the period 2000-2005 was the fastest in the world (data from Food Agriculture Organization). Every year, an estimated of 1,871 million hectare of forest were destroyed. Data from the satellite imaging shows that forest damage each year in every region of Indonesia reaches 5-15\%. Until now (2014), Indonesia has only about 60 million hectares of forests. The main contributing factors for reduction of forests are the causes of forest damage, illegal logging, forest fires, conversion of farms, agricultural land, and development of new settlements (San Afri Awang, 2003). Data from the Ministry of Forestry in 2009 stated that forest damage reached more than 1.08 million hectares per year. Of the 130 million hectares, the remaining 43 million hectares of natural forest in the category.

Consequences for forest damage have caused floods, landslides, and droughts which give rise to social conflicts by taking a great number of lives as well as property in the surrounding communities. Soemarwoto Otto (2008: 
20) states that exploitation of forests for development reasons should be based on awareness and sustainable development policies.

Yuliana Cahya Wulan et al. (2004) stated that the intensity of the conflict regarding forestry in Indonesia from 1997 to 2003 was very striking, indicated by 359 cases. Her study on natural forests from 1997 to 1998 revealed that the period from 1998 to 2000 during the administration of the New Order was known as a period of transition; between 2000 and 2003, the period was coded as a period of decentralization. Conflicts of forest dominance have occurred in the province of East Kalimantan where 106 cases $(30 \%)$ were recorded; followed by Central Java, 47 cases (13\%), North Sumatra 36 cases (10\%) and the province of South Sumatra Province of 12 cases (3\%), and Industrial Forest Agriculture areas (39\%), forest conservation (34\%) and concession area (27\%). Factors involved in general are due to layout limits / restrictions access $(36 \%)$, browsing forests $(26 \%)$, timber theft $(23 \%)$, environmental damage (12\%) and the use of lands (3\%). A study of sustainable environmental management carried out by Malek et al. (2014) revealed that majority of "residents are indeed capable of playing their roles as the agents of managing a sustainable urban environment, due to their abilities and knowledge on the importance of improving the environment".

Bentayan Wildlife Area is one of the six preservation areas in South Sumatra Province. It covers 23.020 Hectares based on decision made by the Minister of Forestry of RI no. 822 in 2013. In 1998, this area has been infiltrated and cleared and made into oil palm and rubber plantations, after the wood was hewn down and burnt. Several traditional communities including Dusun Belido 1 and 2 with a population 983 people (302 KK) live in this area. These villages are currently under the administrative of Desa Simpang Tungkal while Dusun Belido 3 became part of the Desa Suka Damai with a total population 982 people (293 KK).

In Belido 1, 2 and 3, many public facilities such as settlements, roads, and elementary schools (PT. Conoco Philip) are made available and established by the district government with the assistance of Musi Banyuasin, while public health center, Mosque, Pure and remote SMP building were constructed by the Australian government.

The majority of residents $(80 \%)$ are immigrants. Most of them are Javanese, Sundanese, Balinese and Batak. They come from the district - a transmigration area in South Sumatra Province, Lampung, Jambi and Bengkulu. They own land in this area by purchasing from local residents and previous owner.

In addition, people who are on the border of this area are generally the local ethnic population groups such as ethnic Malay Musi, Komering and Ogan. They have occupied these places since the ancient kingdom of Marga. The reality looks at Dusun Penuduan Desa Suka Damai, Bulian and Simpang Sekijing Bentayan Village. They are generally rubber tappers in the area of Bentayan Wildlife Area. The residents continued to flock to the east and north, around the location of the Oil and Gas BOR 6, 8 and 10 PT. Conoco Philip. In order to get these areas they paid 8 million rupiah for each 2 hectars.

The Bentayan Wildlife Area has also become open or easily accessible from the region in the surrounding countryside and forest condition. Most of its territory is occupied by oil and gas company PT. Conoco Philip, the Company HTI (Industrial Plantation Forest) and some oil palm plantation company in the form of bush and rubber and oil palm plantation society.

Animals such as the Sumatran tiger (tigris phantera sumatrensis), deer (Cervus inicolor), Trenggiling (sweet javanica), hedgehogs (hystridae), deer (Muntiacus muncak), Honey Bear (Helarctos malayanus), monkey (Macaca), Crocodile (Crocodylus), birds of Great Hornbill (Buceros), kingfisher (Halcyon tunebris) which used to previously occupy this area are not seen anymore. According to the community, these animals still exist among wild boars and apes. Other animals like Honey Bears still exist and sometimes attack people who are in rubber plantations.

On that basis, Bentayan Wildlife district has changed significantly from the initial or desired state based legislation. 
Table 1. Basic information on the bentayan wildlife area

\begin{tabular}{lll}
\hline Class land closure & (Ha) Wide & $\%$ \\
\hline Bush & 8711,69 & 36,86 \\
Thicket swamp & 68,47 & 0,29 \\
Secondary dry forest land & 498,84 & 2,11 \\
Planted forests & 3203,34 & 13,55 \\
Dry land agriculture plus check & 5416,72 & 22,92 \\
Farm & 159,27 & 0,67 \\
Placement & 134,21 & 0,57 \\
Dry land agriculture & 5350,90 & 22,64 \\
Mining & 90,86 & 0,38 \\
\hline
\end{tabular}

Source: South Sumatra Province (2014).

Table 1 illustrates that the closure of the land in Bentayan Wildlife Area, is actually no longer suitable with the existing provisions in the legislation. As the status of these areas still remain as $\mathrm{BC}$, as a result of the new Minister of Forestry of RI Number: SK. 822/Menhut - II / 2013 About Changes allocation Forest Area in South Sumatra, then the situation should be cleaned and free from human activity. Based on this situation, many questions have arisen regarding the existence of society in Bentayan Wildlife Area.

The Natural Resources Conservation Center role is to protect the integrity of the area, eventually have to deal with people are still living in the area. The strong conflicts which occurred in 2004, 2005, and 2007 have reached an agreement in the form of three selections. However, they have never been applied.

The society has existed for approximately 11 years since 2003. Long before that, people in this region were only looking for a good hunting timber or opportunity to open small farm. Therefore, the biggest question is how to maintain the integrity of the forest area of BC Bentayan and reduce the conflict between the community and The Natural Resources Conservation Center. Accommodating the interests of all parties is the main focus to be solved and conservation areas will be implemented. The present paper will discuss these aspects.

\subsection{Conflicts}

Conflicts in the Bentayan Wildlife Area involve two main parties: the people who live in the area and in the Natural Resources Conservation Center (BKSDA). BKDSA is an agency that has been granted to take charge of the area. The main point of this problem is the reality that the community members in Bentayan have resided in that area and they have agricultural activities. The new rule stated that the Bentayan has to be preserved as conservation area. Therefore, the main focus of this research is to discover the interests of all parties, especially the interests of the local community and how it can be accommodated. At the same time the forest conservation area will be preserved as wildlife area. This problem will be further explored from the conflicts theoretical approach within Environmental Sociology corridors.

\subsection{Theoretical Framework}

When two or more parties are engaged in a conflicting relationship, they do not see eye to eye. Conflict can or not be marked by violence, depending on the differences of real and perceived in terms of the needs, interests and goals or objectives of different parties. The term conflict used in this study is not 'dispute' although both reflects a situation in which people are experiencing factual disputes and conflicts that happen because of their opposing perspectives. Conflict is used because it has a wider meaning of a latent conflict or dispute that is manifested or submitted, including the good that has been or has not been clearly identified, while sengkata only covers the parties involved (Fate Rahmadi, 2010).

Fisher (2001) states that conflict occurs between people are due to their different views on the life and troubles. The views of individuals or groups affected by the background of life, knowledge, experience and capabilities possessed until this difference will affect her life in the face of problems. Dahrendorf (in Ritzer , 2012: 454-455) states that a dynamic society would always have conflict so it is difficult to say that there is no society which does not have a conflict because of the change process is characterized by the ongoing conflict between the elements. A conflict accompanied by violence is a big problem as it causes loss or destruction of life within the 
community. Conflict has to be managed in order to produce unity to ensure progress in the life of the community. Each conflicting element in the community may contribute to social disintegration. He classified group conflict into three broad groups: firstly, group or assemblage acting like position with interests similar role; secondly, interest groups, the group that is the true agent of conflict, recruited from the groups; and thirdly, the conflict, the people really involved in the conflict. Conflict theory views that the frequency found in the community just because of pressure or coercion from above by the power of the ruling classes. Not the result of consensus but a tool of the dominant group to impose its interests to minority groups.

The view above also pointed out that in a conflict, artificial groups and interest groups are usually involved too. In group dummy, directions and forms of conflict are not too flashy, but then can be picked up after the turn into the conflict of interest then becomes more open.

San Afri Awang (2011) stated that conflict management of natural forest resources has misunderstood the relationship between the stakeholders with the resources, both in terms of knowledge, rules, interest and use, which may often cause damage. Educational programmes for rural communities is vital for improving socio-economic and social well-being among people in rural community (Abdul Razaq, Mohd Mahzan, \& Wan Hasmah, 2013). Fisher (2001) distinguishes between violent conflicts. Presented conflict is "the relationship between two or more parties (individuals or groups) who have, or find that it has inconsistent targets, while "violence produced" includes actions, words, attitudes, various structures or systems that cause physical damage, mental, social or environmental, and/or preventing a person to achieve full potential." On this understanding, the conflict at any time if allowed to persist can significantly be forceful. Thus violence is one tangible form of conflict.

Galtung (1958) explains that the source of conflict is due to the force structure, culture, and direct action. Structural violence refers to the action by individuals or groups in a social system or institution that has the absolute authority to determine policy. Policy appears to pose discrimination, social injustice within the system so that life becomes uncomfortable, alienated and increasingly difficult to meet the needs principle, the emergence of unemployment and poverty. Conflicts caused by the culture such as values, beliefs, customs, ethnic or religious community to inculcate certain violent attitudes and behaviors of hatred, fear and suspicion against an ethnic group and religion or other ideology consequently raise the living conditions of discrimination, inequality and injustice. While the conflicts caused by direct violence among other acts of violence such as the existence of threats and beatings or abuse by one member of the group to another group may result in resistance and unrest.

Causes of conflict vary. In the context of conflict between communities associated with the policy, the cause of conflict seems more complex. Theoretically, there are three variables of conflicts, namely, inequality, exploitation and domination (William Perdue, 1986, in Prayogo, 2005: 22). Rahmadi Fate (2010) presents a number of theories of conflict and of government, namely, the theory of public relations, principles of negotiation theory, identity theory, and the theory of misunderstanding, transformation theory and the theory of needs. Based on the theory of public relations, conflict occurs because of the polarization of suspicious and Rivalry groups in the community. Therefore, it is necessary to increase communication to create mutual understanding between the parties involved in the conflict and efforts to develop a tolerance to accept diversity in the group.

According to Fisher (2001: 96), conflict can be explored in several ways including handling, rejection, compromise, problem solving, and accommodation. Each approach has its own strategies and distinctive characteristics. This approach also distinguishes between concern for the goals and concern for relationships. Surely this must be adapted to the reality of the problem and the purpose to be achieved. Control-based approach has the characteristic of being impatience with dialogue and more nuanced pressing or forcing, while rejection has a more direct approach on the aspect discussed to escape from the conflict. Compromise approach leads to a bargaining position only, and do not arrive at a more strategic solution region. Meanwhile troubleshooting-based focuses on efforts to keep a good relationship, achieve target as well as be more effective. Accommodation emphasizes on the aspects of accepting everything and surrenders to the status quo. This study tried to take the point of view of technical problem solving approach. 


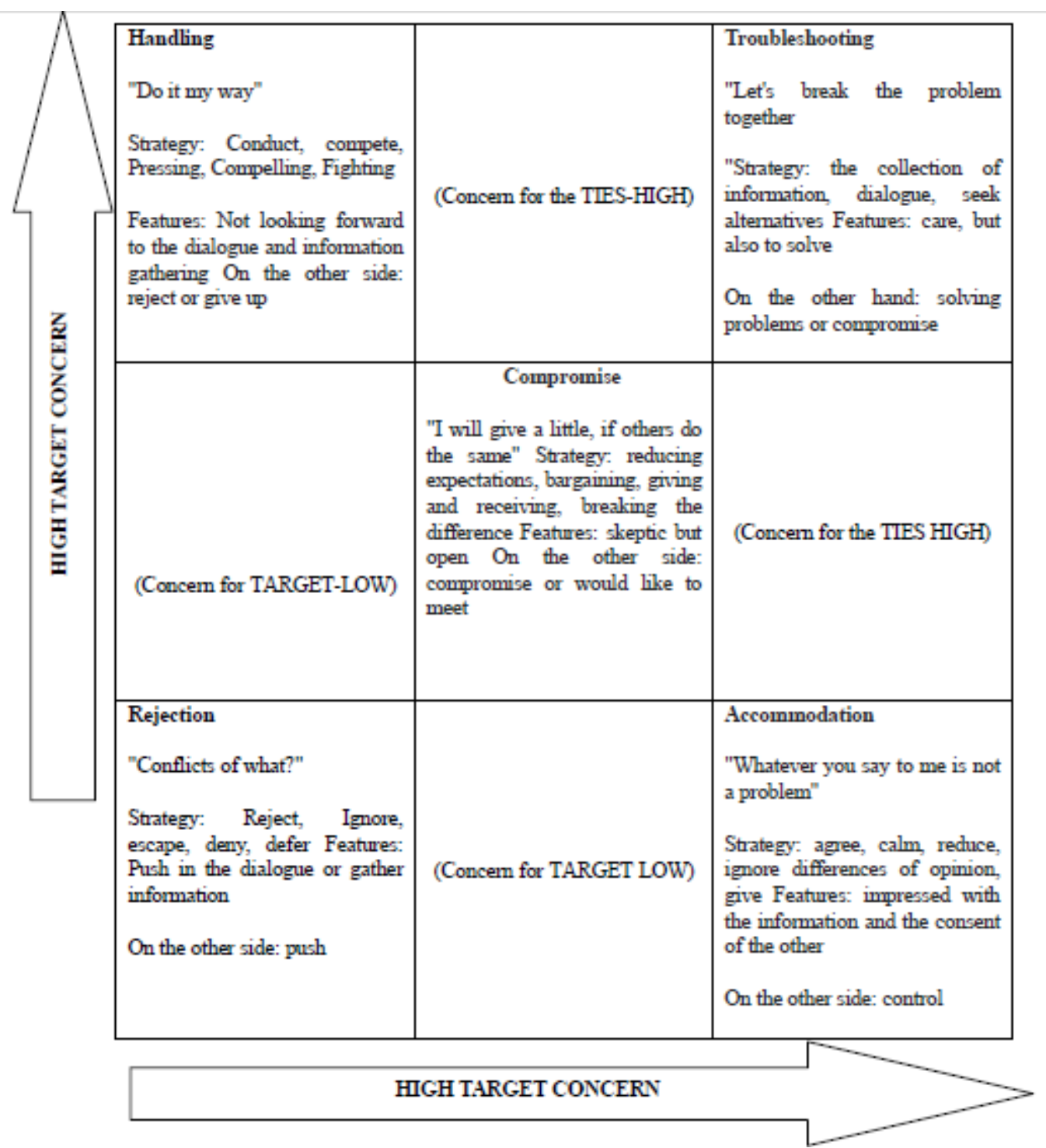

Figure 1. Conflict Management Approach (Simon Fisher et al., 2001: 96)

This study tried to see the problem resolution (see Figure 1). There is a concept of win- win solution that can be used in the region by conducting a trial problem resolution. In the current case, the aspect of the participation is vital. Participatory approaches are generally used in the development of society as an alternative to address the weaknesses of the approach from the top down (Trickle -down approach) that people are regarded as objects of the implementation of development, which is incompatible with the environmental conditions and the needs of the community. Community participation approach is seen not only as an object or the lovers of the development, but more seen as subjects or actors in the implementation of its development.

Hobley (1987) stated that actual participation is an involvement made by any individual or group on the basis of the community's own against a perceived benefits, while participation includes all activities from the beginning to the end of the process (Awang, 2003: 157). Furthermore, active entries and meaningful involvement of the mass population in different levels as (1) in the decision making process to determine community goals and the allocation of resources to achieve the goals that have been established; (2) implementation of programs and projects on a voluntary basis and are evenly split, (3) the result of a program or a project.

In order to increase community participation [Ife (1995) in Suprayitno (2010)] states that the community needs to feel important, recognize the benefits for their lives, and be aware of the opportunities to participate well in the structure and process.

Rober Chamber (1992) stated that in order to increase participation, the community members should be involved in research, the formulation of the plan of activities and the implementation process until the evaluations. One 
implementation of this model of participatory approaches have been made by LePMIL, a non-governmental organization in South Sulawesi Province in addressing conflicts of forest management of natural resources in the forest " Nipa Nipa and nanga nanga" . It focused on improving the ability of all stakeholders in the forest on the implementation of the participatory approach.

The above description and understanding of the social reality is an important aspect in understanding the entries. In this case, it can be said that the participatory approach is well-received, because a lot of frustration has been manifested due to the shortcomings in the classical researches. Implementation of classical research results in total and exclusive control over the process and the results of research by professional researchers. The researchers of the present study developed knowledge based on data collected from various individuals, groups and institutions in the community. Individuals, groups and the agency have no control at all on the knowledge generated from data obtained from them. All of them are mere objects (Fernandez and Tandon, 1993: 8). Conflict management of natural resources, with emphasis on patterns of participation and involvement of community groups-related elements in the roots of the conflict management process, arrives at a solution. Guidelines on conflict resolution, all of which depart from the common understanding, an agreement, based on the awareness of environmental ethics, will be able to bring a solution to a more cultural participation or non-litigation to ADR pattern. In the words of the Centre for Democratic and Government (AI), it is mentioned that ADR is not a legal mechanism that replaces the role of positive law. Both are able to operate, even side by side. ADR practically realized in the form of negotiation, conciliation / mediation, and arbitration. Negotiations have accommodated the interests of the parties, without doing an intervention. In this process, the mediation process can be involved through the middleman. The center is considered a third party not involved in the conflict while arbitration model is putting a third party as a mediator and is allowed to take decisions on conflict resolution (CDR, 1998; 4).

ADR processes, mediation mechanism is an important factor, as it is here to observe whether the mechanisms outside the court are in effect. Thomas R Kline (2006: 5) says that the mediation process may occur outside the context of litigation, as it can be preceded by a process of arbitration, and other mechanisms. Clearly, ADR requires the mediation, and the third very important role in this context (Schale up, 2011). Implementation of ADR mechanisms will be able to provide the maximum benefits to all parties to the conflict. The main advantage is a win - win solution, everyone is a winner and all share the profits. In the context of natural resource conflict, ADR mechanisms can be used, as an alternative to the deadlock in the positive law.

\subsection{Theoretical Framework}

The purpose of the study was to understand the interests of all parties involved in the conflict areas Bentayan Wildlife, desires and expectations of the community. The management of this conflict could not be introduced until the end of conflict management model that can accommodate the interests of the community in an effort to restore the function of the Bentayan Wildlife Area.

\section{Method}

This is a qualitative study using a case study research design (Creswe, 1998:36). Data was collected by using in-depth interviews and group discussions (focus groups) with community leaders and community members who are involved in the conflicts either directly or indirectly. Respondents involved 40 people [four officers, two village leaders, two officers of the Kacamatan Tungkal Jaya, one DPRD Musi Banyuasi member, two groups of Village Consultative Body from Desa Simpang Tungkal and Desa Suka Damai, five Heads of Dusun (Belido 1, 2 and 3, Penuduan, Bulian and Simpang Sekijing), six community leaders, and 18 community members).

\section{Results and Discussion}

This study aimed to obtain a model of conflict management that can accommodate the interests of all parties in the Bentayan Wildlife Area. Therefore, the study started by pointing out the policy emphasis on conflict transformation theory from Simon Fisher (2001), where the conflict can be resolved by ensuring that the interests of all parties are restored.

Important considerations that need to be done in dealing with the conflict of Bentayan Wildlife are as follows:

a. A conflict that stems out from the question of the structure is a structural conflict. It can be interpreted that conflict, starting from the arrival of people to the area Bentayan Wildlife, is the question of structural inequality. All staff interviewed admitted that they already know and understand that the site is occupied by the Wildlife, and is prohibited. But they have no other choice because of the limitations of the access the resources of nature for economic life. Due to the policies of local governments to provide business licenses at several locations at the oil palm plantation company. In addition, some areas of the forests are owned by HTI (Industrial Plantation 
Forest) in this region and this there is no vacant land that can be used by the public. Their goal is to enter the Bentayan to find a new life by opening farmland. Inability to work elsewhere and limitations of belonging force them to work on a prohibited ground. It is recognized and noticed by people. Obviously this is a structural issue, because in the context of stateless systems in Indonesia, citizen access to economic assets must be guaranteed by the state. National capability in ensuring the economic life of the people continues to increase every year, then conflicts that occur in the environment, including in the area of Bentayan Wildlife becomes an issue.

b. Based on the statement of the region Belido 1, 2, and 2, most residents in the province of Bentayan Wildlife Area are permanent residents. This is the initial site of entry of the citizens. Hundreds of houses have been put up and the community has opened their own farm. They have lived in the area, created rubber estates, and produce a livelihood for more than 10 years. They've been living in this region, just like a final settlement and the village has been recognized as part of the territory in the surrounding countryside. They have citizenship identity cards and participate in activities conducted in the village.

c. The lack of coordination among government forces has resulted in increasingly strong opposition among the community of Bentayan. Before the development of Bentayan, this area did not have any facilities. All the facilities were then developed by the local community and they were quite complete. Due to people activities in this area, the facilities developed including the Rural Health Center (led by a village midwife), State Elementary School building and SD- SMP, PLN electricity and proper road. These entire infrastructures were developed by the government based on the initiative of the village government and local governments. This development has been carried out without Natural Resources Conservation Center (BKSDA) involvement, but from the community perspectives, they viewed Natural Resources Conservation Center (BKSDA) to be the government.

d. In reality, there is no more wildlife in Bentayan that must be protected. This is actually the effect of the inclusion of community to the area. This might be due to the "Connivance" of that place for almost 10 years as a result of the concessionaire / HTI which leads to various activities such as the opening of Oil and Gas and oil palm plantations that necessitate prior development of roads and driveways in the area. This situation is a result from community activities in this area. The natural forest and wildlife are no longer ecologically functional in that area.

e. The local communities in Bentayan should be seen as citizens of Indonesia, where they have occupied the region. They should be treated as Indonesian citizens - should be placed as an important consideration. They have the same rights as other citizens which are to be protected, while holding the same obligation to comply with existing regulations. The regulations set on the Bentayan wildlife, since the beginning of determination, are essentially the rules made in the spirit of giving good aspects and benefits to all parties, especially the community.

f. On this assumption, the forest area is not to create new problems or conflicts in the community. The forest area should be functional and beneficial for the community and the next generation.

g. BKSDA South Sumatera position is basically an extension of the government through the Forestry Department to carry out the rules of the Bentayan Wildlife Area. BKSDA will be subjected to the provisions of the law. When the status of law is for Wildlife, there is an obligation to protect and safeguard BKSDA region. With this assumption, the action of BKSDA is very dependent on the legal basis of their platform in action. Here is the basic question of the point, whether the rules remain as it is now, and BKSDA will remain in position "face" with the community.

h. Three option agreements (inclave, damages, and translok) achieved in 2007 and turned out to not be feasible. The resolutions have actually been recovered, but have constraints or failed in the application. 3 options resolution applications can be done if the government is able to do that, but the fact is difficult for the government to implement it.

Important considerations will be taken based on the proposals which are put forward for resolving conflicts in Bentayan. Based on the foregoing, the next step is setting conflict resolution mechanisms through non-legal mechanisms. In other words, this is closer to the concept of alternative dispute resolution (ADR), although not pure ADR, because the emphasis is not on aspects of mediation. This is not the last of the understanding that it is a conflict of structural Bentayan SM, namely the inability of the country to meet the people's basic rights.

This application model includes the Bentayan to preserve the long-term benefits. However, it can be said that the reality of the occurred situation is more complex. Therefore, it is very crucial to implement this model now. The existence of communities in Bentayan should not be seen as marginal, and their presence should be maximized in order to take care of the forest area to ensure her well-being. According to Fisher (2001) a conflict with high 
resolution can survive in the long-term resolution by taking accommodative measures. This measure will be implemented with a participatory mechanism.

Below are a range of strategies that can be done to implement this resolution model:

a. Mapping the area comprehensively. This is a crucial point in determining how the area can be treated and be open to the society, good for the farm, public / social, and placement. Mapping is also important to determine and categorize the area of the forest whether it is still empty or untreated by the community. Moreover, the mapping is also useful to reorganize the zone of Wildlife in Bentayan. Mapping of the area should be done with the involvement of various elements related, cross-disciplinary nature of knowledge. Not only the social sciences alone, but also to the contribution of knowledge of biology, forestry, anthropology, ecology, planology and communication. All should be involved so that the data collected is comprehensive and accommodate all needs in implementing the redevelopment of this area.

b. Start building intensive and participatory dialogue with community members at the Bentayan area is crucial. Dialogue is to emphasize the importance of the Bentayan Wildlife park and network solutions offered as a middle way. The community should be considered as part of the forest area, not as pests or forest browser.

c. Build a consensus with the community, the village government, district, custom elements, a formal law about the status of the Bentayan Wildlife area and efforts will be made going forward. Details of the actions that have been previously described as a household should be made an agreement, and it will also be extended to other aspects.

d. Involving a third party as a facilitator or mediator in raising community participation to be looked at the Bentayan Wildlife Area as a strategic area. These third parties may originate from among the college or NGO capacity to be responsible for implementing community-based forestry.

e. Performing an intensive coordination with relevant government elements, especially village and district government. The aim is to build synergies for re-foresting the Bentayan Wildlife Area approaches without conflict and violence. Government policies at the village and district level can be adjusted so as not to be policies that interfere with the spirit of forest conservation.

f. The formation of specific groups or specific organization that originated from the community itself and involves elements of government (BKSDA) and third party, with the main task is to maintain the existing agreement. The existence of this group is important, because the agreement must be maintained and monitored.

g. Reforestation activities and the determination of the limits of Bentayan Wildlife Area and reconstruction must engage the community so that the community benefits from this activity and thus is responsible for the preservation and maintenance. This is not the last of the fundamental basis of conflict management sustainability, empowerment, and well-being. In summary, the model of conflict resolution should be able to accommodate the interests of all parties; both society and government, so that conflicts can be minimized. This can be seen in the chart below. 


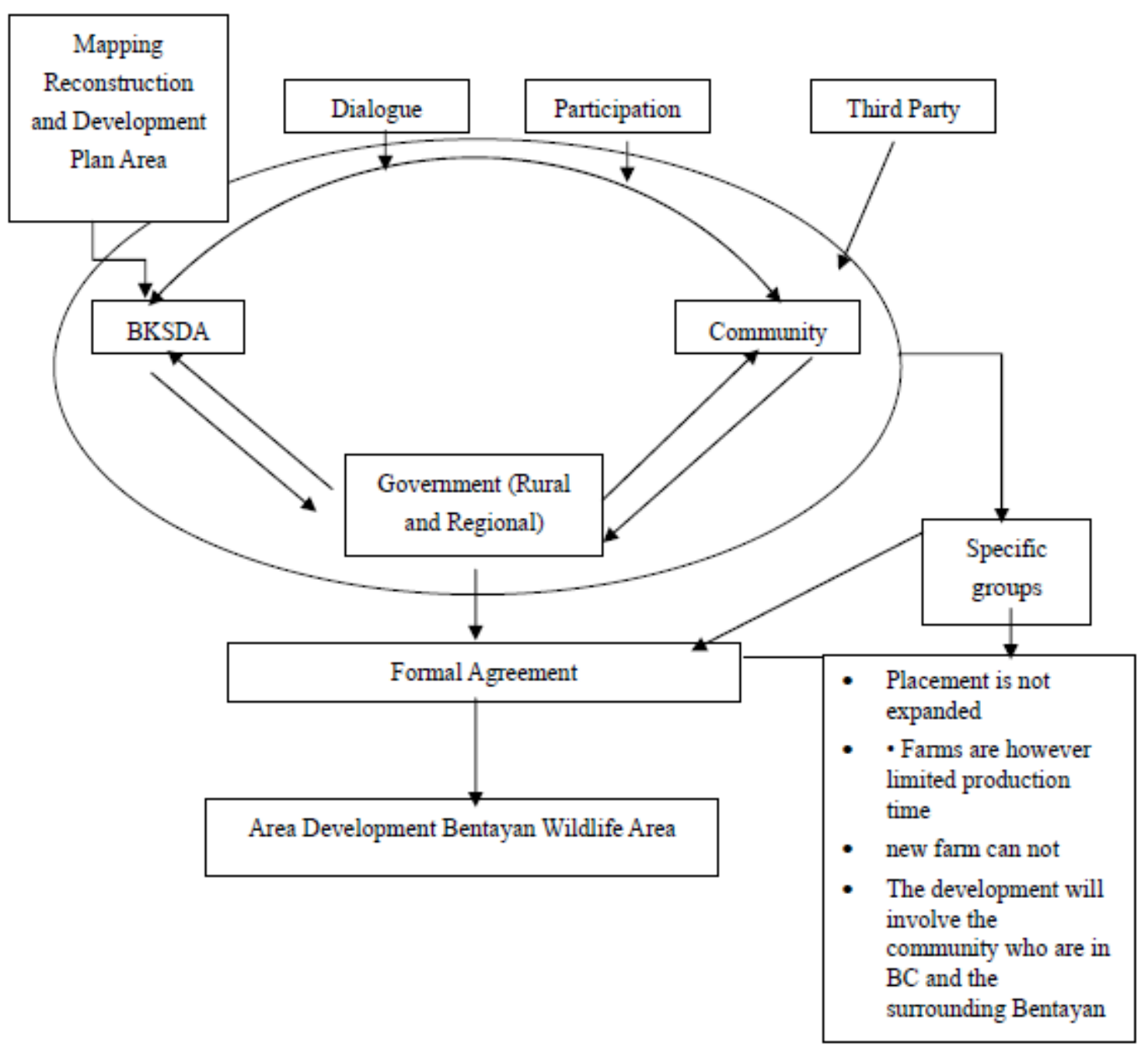

Figure 2. Conflict Management Model of Bentayan Wildlife Area to accommodate the interests of society

The above model can be an alternative conflict management strategy for Bentayan area, but it must be preceded by a strong commitment from the government (BKSDA). Umbrella policy should be given to provide strength to the program which will be further able to operate properly and consistently. Spearheading the implementation of this model should start from the government. Government should move the existing mechanisms until the solution - the solution can be implemented.

The practical model described above can be said to be ready for upgrade. just that the application needed further testing with a different approach. In general, the above model can be used as a scheme to understand the problem in finding a more comprehensive solution and the best resolution. Therefore the model should be elaborated deeply, especially in terms of weaknesses and strengths.

The strengths and weaknesses of the model is analyzed using SWOT (Strength, Weakness, Opportunity, Threats). The following is the explanation of the analysis.

\subsection{Strength}

a. The government has a position as an institutional guardian and protector of the community. Although communities in Bentayan violate the provisions of the forest asylum, but the government did not reject the paradigm that they are a guardian of society, who should be able to find the best solution.

b. People who live in the forest area of Bentayan know that the area is accessible and open for any activity.

c. People want and are always open to dialogue with the government (BKSDA) that there is a possible way out of their problems (demonstrated by the solution 3 options in 2007). 
d. BKSDA will be subjected to formal legal government policies. Whatever the decision is, as long as the rule of law has to be followed and implemented by BKSDA.

e. The issue of conservation is a global issue and the ability to carry out conservation activities adds value to the country's image. Provide dates defining the periods of recruitment and follow-up and the pnmary sources of the potential subjects, where appropriate. If these dates differ by group, provide the values for each group.

\subsection{Weaknesses}

a. The society understands about the function of Bentayan's Wildlife Area still varied. Some members of the community do not know for certain about the functions of the forest preserve, Forest Production, Limited Production Forest with all the rules.

b. There are already some basic infrastructures built in that place. It appears from elementary schools, the Health Centre, houses of worship, village roads, and the grid.

c. Regions BC Bentayan is regarded as the main source of livelihood among local residents. They generally do not have more land elsewhere and only dependent on the existence of land in Bentayan.

d. Number of members of BKSDA to do surveillance on the Bentayan is very minimal. In several visits to BC Bentayan, almost no BKSDA officer was on site. The post guard is broken and never occupied.

e. Lack of explicit coordination among relevant agencies such as local government agencies and BKSDA often results in conflicts between government programs and the policies of BKSDA.

f. There are unclear border area and population of the outstanding areas in the forest of Bentayan.

g. The existence of politicians who promise to the community to strengthen the community's existence in this area.

\subsection{Opportunities}

a. The existence of the rule of law, the example of other BC areas and the pattern model as exemplified above have been implemented.

b. There are still more vacant areas in Bentayan which are not used by people.

c. There is a convenient access to transport and communication in the vicinity of Bentayan Wildlife Area to facilitate the inventory and monitor the area.

d. There are sufficient motivated personalities among the local community leaders in managing the citizens that consultations and dialogues are easy to be carried out.

e. Some settlements in the society are still relatively new and unopened permanently. This makes it easy to limit further expansion.

\subsection{Threats}

a. There are many immigrant residents who have started a farmland in Bentayan but did not reside at the location. This happens due to the practice of buying and selling land among citizens.

b. Open area residents are prevalent, especially with the influx of new immigrants' citizens.

c. The population is increasing and they need new land to occupy.

d. There is political involvement gain political support.

e. The time required is long enough to control the process so that the Bentayan Wildlife Area can be restored. The minimum time required is about 30 years, which is duration to adapt to the age of a productive society. This potential inconsistency has occurred half way.

The SWOT analysis above indicates the unity of the elements, out of which a model of conflict resolution may be proposed such as the followings:

a. An intensive dialogue and communication with the citizens should be performed with the emphasis on the important aspects of conservation in finding the best solution to avoid violent conflict between citizens and government.

b. Forest conservation status of Bentayan should be promoted and fixed in the long term by limiting the accessibility of people in the forest.

c. People should be allowed to continue living in the area Bentayan Wildlife Area, but they should not be allowed to live for extended period of time, but instead the duration should be fixed. 
d. Perennials plants should be planted and the types of plants should be determined based on the age of the plants and cannot be rejuvenated. Rejuvenation should only be allowed for forests plants that have been determined.

e. A special group to control programs should be formally formed with the aim to keep the policy consistent again based on a clear umbrella law.

f. Bentayan development efforts should be made well organized in order to involve and benefit the whole community.

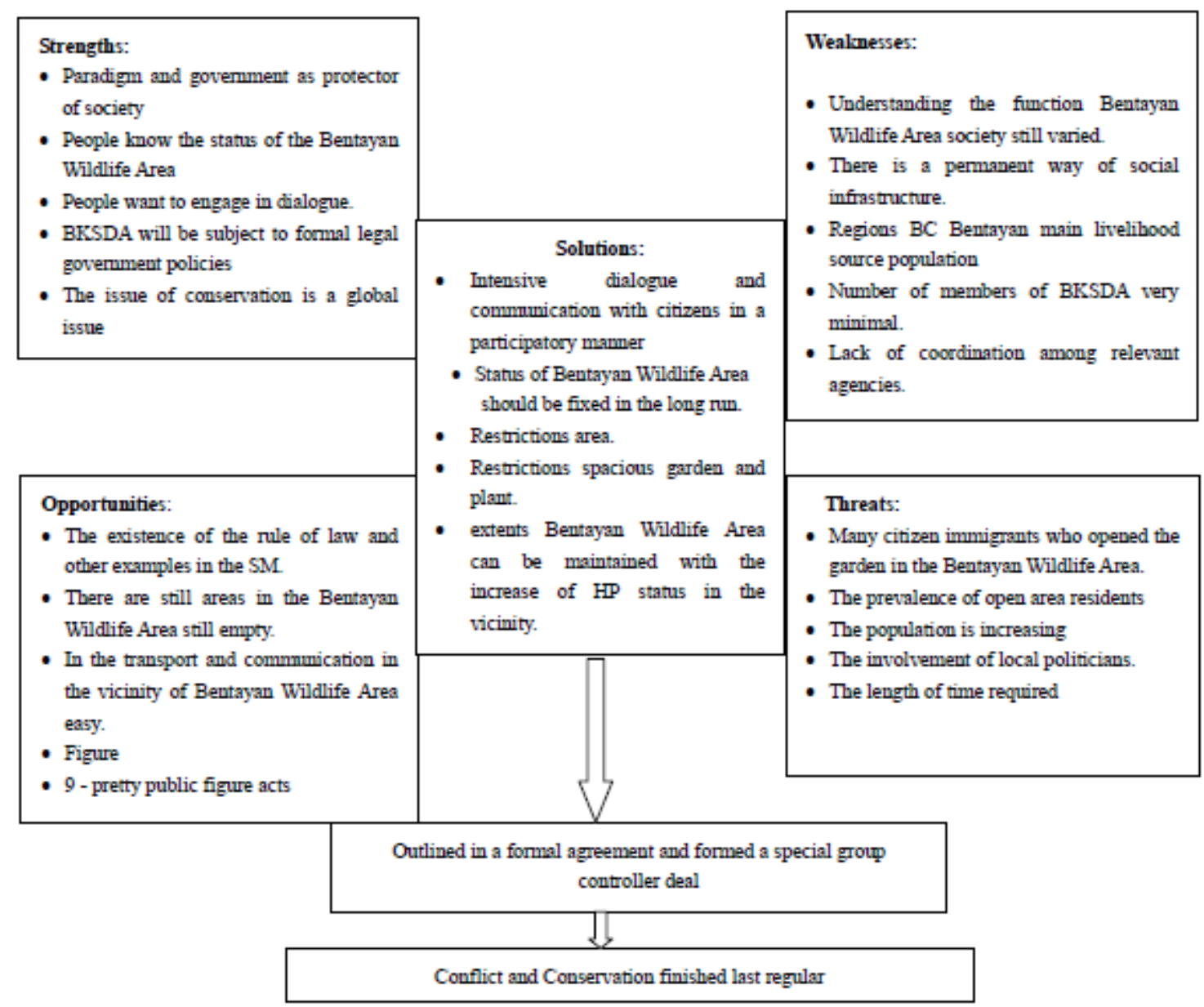

Figure 3. SWOT analysis as an alternative conflict management in bentayan wildlife area

Based on to the matrix SWOT analysis above, this alternative is one of the most possible to be carried out. However, it is a challenging task to be consistent in controlling the process, while it can only happen if it is carried out completely. Although it is seriously challenging, it can be overcome by creating a rule of law that are clearly against the agreement, and maximize community involvement.

\section{Conclusion}

Results from this study highlighted the importance of local community engagement in policy making with authority bodies. It has been found in this study that conflict increases from the question of the structure. People come to the restricted site to find basic necessity for living and livelihood which they cannot find elsewhere. It is common in many countries for people from around the world to explore forest area for vairous purposes including for research activities, recreations, learning camps and etc. Within the Bentayan Wildlife Area, some groups of communities who reside and establish gardens in the area are the only groups who do the gardening just because of their placement in the region surrounding the countryside as they assume that the Bentayan Wildlife Area as a potential source of income. While this happening is in the direct opposite of the BKSDA duty to maintain and manage the area, the groups who are linked to the conflict with government officials in the 
district need to be provided with reinforcement about the existence of the community in this area. In addition, NGOs and communities also need to advocate BLH in order to achieve a fair treatment from the government, especially BKSDA. In order to implement the conflict management in Bentayan Wildlife Area that accommodates the interests of the community, it is important to do the mapping of the area, increase the intensity of communication in order to conduct dialogue and consultations so that agreements are equally achieved to benefit the whole society in particular and the redevelopment of Bentayan Wildlife Area in general. Therefore, institutions or community groups who can represent the community and professional mediator should play their role as facilitators as well as controllers so that the agreement that would be made may determine and secure a success in the implementation. The status of forest areas should remain prominent, while the existence of the community should play their role and serve as a "guardian" of the conservation area so that it reaches a certain level, whereby they would already have the ability to go out and start a new venture in other areas. For this, it takes a serious effort to control the processes that take place in the area. The current study proposes an integrated model for conflict resolution that can be used as framework for preservation of forestry and wildlife area.

\section{References}

Abdul, R. A., Mohd, M. A., \& Wan, H. W. M. (2013). The Effectiveness of Human Development Programmes in Improving Community Wellbeing. Australian Journal of Basic and Applied Sciences, 7(9), 51-57.

American Psychological Association. (1972). Ethical standards of psychologists. Washington, DC: American Psychological Association.

Anderson, C. A., Gentile, D. A., \& Buckley, K. E. (2007). Violent video game effects on children and adolescents: Theory, research and public policy. http://dx.doi.org/10.1093/acprof:oso/9780195309836.001.0001

Awang, A. S. (2003). Political Community Forestry. Yogyakarta: Center for Critical Social Studies (CCSs) Collaborate with Creative Discourse Yogyakarta.

Awang, A. S. Wiyono, B. E., \& Sudiyo, S. (2007). People of the Forest Management Unit: Knowledge for Land Process of Construction. Yogyakarta: Banyumili Art Network Working with the Forest Research Centre People's Faculty of Forestry UGM.

Beck, C. A. J., \& Sales, B. D. (2001). Family mediation: Facts, myths, and future prospects (pp. 100-102). Washington, DC: American Psychological Association. http://dx.doi.org/10.1037/10401-000

Bernstein, T. M. (1965). The careful writer: A modern guide to English usage (2nd ed.). New York, NY: Atheneum.

Bjork, R. A. (1989). Retrieval inhibition as an adaptive mechanism in human memory. In H. L. Roediger III, \& F. I. M. Craik (Eds.), Varieties of memory \& consciousness (pp. 309-330). Hillsdale, NJ: Erlbaum.

Blowers, Andrew and Thompson, Grahame. (Translator Paul Sitohang). Inequities. (1983). Conflict and Change. Jakarta: University of Indonesia.

Bruno, Verbist and Gamel, Pasya. Historical perspective Forest Area Status, Conflict and Negotiation in West Lampung Resources are. Lampung Province. Agrivita. Volume 26 \# 1

Burke, P. (2011). History and Social Theory. Jakarta: Yayasan Indonesia Torch Reader. http://dx.doi.org/10.1007/s11186-011-9150-8

COSER, A. L. (1957). Social Conflict and the Theory of Social Change. The British Journal of Sociology, 8(3), 197-207. http://dx.doi.org/10.2307/586859

Cress, C. M. (2009). Curricular strategies for student success and engaged learning [PowerPoint slides]. Retrieved from http://www.vtcampuscompact.org/2009/TCL_post/presenter_powerpoints /Christine\%20Cress\%20-\%20Curricular\%20Strategies.ppt

Creswell, J. (1998). Qualitative Inquiry and Research Design. USA: Sage Publications.

Dahrendorf, Ralf. Toward a Theory of Social Conflict (Akademie fur Gemeinwirtshaft, Hamburg, Germany). Conflict Resolution. Volume II NUMBER2.

Driedger, S. D. (1998). After divorce. Maclean's, 111(16), 38-43.

Fink, M. C. (2006). Difficulties in the Theory of Conflict. Centre for Research on Conflict Resolution. The University of Michigan. Volume XII. Number 4.

Fisher, S. (2001). Managing Conflict, Skills and Strategies for Action. USA: Zed Books Ltd.

Gibbs, J. T., \& Huang, L. N. (Eds.). (1991). Children of color: Psychological interventions with minority youth. 
San Francisco, CA: Jossey-Bass.

Gilbert, D. G., McClernon, J. F., Rabinovich, N. E., Sugai, C., Plath, L. C., Asgaard, G., ... Botros, N. (2004). Effects of quitting smoking on EEG activation and attention last for more than 31 days and are more severe with stress, dependence, DRD2 A 1 allele, and depressive traits. Nicotine and Tobacco Research, 6, 249-267. http://dx.doi.org/10.1 080/1462220041 0001676305

Goleman, D. (2009). What makes a leader? In D. Demers (Ed.), AHSC 230: Interpersonal communication and relationships (pp. 47-56). Montreal, Canada: Concordia University Bookstore. (Reprinted from Harvard Business Review, 76(6), pp. 93-102, 1998).

Guignon, C. B. (1998). Existentialism. In E. Craig (Ed.), Routledge encyclopedia of philosophy (Vol. 3, pp. 493-502). London, England: Routledge.

Harmantyo, D. (2007). The regional expansion and spatially Conflict. Journal of Makara, Science, 11(1),

Healey, D. (2005). Attention deficit/hyperactivity disorder and creativity: An investigation into their relationship (Unpublished doctoral dissertation). University of Canterbury, Christchurch, New Zealand.

Herculano-Houzel, S., Collins, C. E., Wong, P., Kaas, J. H., \& Lent, R. (2008). The basic nonuniformity of the cerebral cortex. Proceedings of the National Academy of Sciences, 105, 12593-12598. http://dx.doi.org/10.1073/pnas.0805417105

Heryawan, A. (2009). Regional Autonomy and Regional Pemekaran Without Anarchy, http://www.ahmadheryawan.com/kolom/94-kolom/1721-autonomy-district-and provincial-pemakaran-without-anarki.html,

INIS (Indonesia-Netherlands Cooperation InIslamic Studies) and the Centre for Language and Culture Syarif Hidayatullah State Islamic University Jakarta. 2003 Community Conflict in Indonesia Current. Leiden-Jakarta.

IFE, J., \& Frank, T. (2008). Community Development, Alternative Social Development in the Era of Globalization. Translated writer Manullang, Nurul Yakin, \& M. Nursyahid. Yogyakarta: Oxford University Press.

IFE, J. (2002). Community Development: Community Base Alternatives in an Age of Globalisation, Second Edition. Australia: Pearson Education Australia Pty. Ltd.

Iskandar, Z. (2005). Conflict in Bangka Tin Mining Area - Belitung. Jakarta: LIPI Press.

Iskandar, J. (2001). Man, Culture and Environment, Human Ecology Review, Humanities Press, Bandung.

Iskandar, J. (2009). Human Ecology and Sustainable Development, Environmental Science Masters Program, UNPAD Press, Bandung.

Iskandar, J. (2012). Ecological Farming The Baduy (Based Forest Management Sustainable Traditional). Bandung: PT. Alumni.

Jalaluddin, A. M., Abdul, R. A., Mohd, M. A., \& Alfitri. (2014). Symbiotic Relationship Between Telecentre And Lifelong Learning For Rural Community Development: A Malaysian Experience. TOJET: The Turkish Online Journal of Educational Technology, 13(3), 148-155.

Klimoski, R., \& Palmer, S. (1993). The ADA and the hiring process in organizations. Consulting Psychology Journal: Practice and Research, 45(2), 10-36. http://dx.doi.org/10.1037/1061-4087.45.2.10

KSDA Sumsel. Regional Office of South Sumatera Province. Department of Forestry \& Gardening. (1999). Conservation Area Information Prov. Sumsel.

Kubrick, S. (Director). (1980). The Shining [Motion picture]. United States: Warner Brothers.

Liliweri, A. (2005). Prejudice and Conflict. Yogyakarta: LkiS.

Liu, S. (2005, May). Defending against business crises with the help of intelligent agent based early warning solutions. Paper presented at the Seventh International Conference on Enterprise Information Systems, Miami, FL. Abstract retrieved from http://www.iceis.org/iceis2005/abstracts_2005.htm

MacIntyre, L. (Reporter). (2002, January 23). Scandal of the Century [Television series episode]. In H. Cashore (Producer), The fifth estate. Toronto, Canada: Canadian Broadcasting Corporation.

Malek, J. A., Ahmad, A. R., Awang, M. M., Ahmad, J., \& Alfitri. (2014). Sustainable Environmental Management and Preservation Knowledge among Multi-ethnic Residents. Asian Journal of Scientific 
Research, 7(4), 546-560. http://dx.doi.org/10.3923/ajsr.2014.546.560

McLuhan, M. (1970a). Culture is our business. New York, NY: McGraw-Hill.

McLuhan, M. (1970b). From cliche to archetype. New York, NY: Viking Press.

Mellers, B. A. (2000). Choice and the relative pleasure of consequences. Psychological Bulletin, 126, 910-924. http://dx.doi.org/10.1037/0033-2909.126.6.910

Mundung, S. J. (2007). Analysis of the Conflict between Riau Province Lands Community of States (2003-2007). R \& D Data FKPMR.

O'Bren, Jay. (1993). Ethnicity National Identity and Social Conflict. Nordie Journal of African Studies, 2(2), $60-80$.

Postman, N. (1979). Teaching as a conserving activity. New York, NY: Delacorte Press.

Postman, N. (1985). Amusing ourselves to death: Public discourse in the age of show business. New York, NY: Viking.

Rahmadi, F. (2010). Mediation Solution Through consensus approach. Jakarta: PT. King Grafindo Persada.

Ritzas, G., \& Douglas, J. G. (2004). Modern Sociological Theory. Jakarta: Prenada Media Group, 1980, Sociology, A Multiple Paradigm Science, Allyn and Bacon, Inc., Boston, London

Ritzer, G. (2012). Sociological Theory, From Classic to Latest Developments Posmodern, Oxford University Press, Yogyakarta

Robert, K. Y. (1997). Case Study (Design and Methods). Jakarta: PT. King Grafindo Persada.

Robert, H. L. (2003). Perspespektif About Social Change. Jakarta: PT. Create Rineka.

Robiyanto, H. S. (2010). Swamp Management Strategy for Sustainable Agricultural Development. Indralaya Ogan Ilir: Land Department Faculty of Agriculture University of Sriwijaya.

Prayogo, D. (2009). Corporate Conflicts Between Local Communities. Jakarta: FISIP UI Press.

Saad, Z. (2005). Strengthening of the Capacity Management Cobflict \& Agencies at District and Village Community Institutions. European Union: South Sumatra Forest Fire Management Project.

Salim, A. (2001). Theory and Paradigm for Social Research, Tiara Discourse, Yogyakarta. Zukri Saad. 2005 Strengthening of the Capacity Management Conflicts \& Agencies at District and Village Community Institutions. European Union: South Sumatra Forest Fire Management Project.

Scale, U. (20101). Understanding and Practice Study Alternative Conflict Resolution Conflict Mediation SDA institutions in the Province of Riau, Jambi, West Sumatra, and South Sumatra, Scale Up, the Ford Foundation, Pekanbaru

Semenak, S. (1995). Feeling right at home: Government residence eschews traditional rules. Montreal Gazette, p. A4.

Simon, F. (2001). Managing Conflict (Skills and Strategies for Action). London: The British Council Indonesia Smk. Graphic Desa Putra.

Soemarwoto, O. (2005). Synergy Development Environment. Yogyakarta: State Printing (Printing \& Publishing). Ecological Environment and Development. Bandung: Djambatan.

Strong, E. K. Jr., \& Uhrbrock, R. S. (1923). Bibliography on job analysis. In L. Outhwaite (Ed.), Personnel Research Series: Vol. 1. Job analysis and the curriculum (pp. 140-146). http://dx.doi.org/10.1037/10762-000

Sumarjan, L. (2007). Media Solutions Land Through consensus approach. Jakarta. PT. King Grafindo Persada.

Supratpo, E. (2003). Forestry Fruiting Violent Conflict. Peek Forest (May-July 2003)

Suyanto, B., \& Sutinah. (2005). Methods of Social Research (Various alternative approaches). Jakarta: Prenada Media.

Turner, S. B. (2012). Social Theory From Classical Until Postmodern. Yogyakarta: Oxford University Press.

Yasmi, Y. (2003). Understanding Conflict in the Co. - Forest Management, the Case on Bulungan Research Forest. International Forestry Review, 3(1).

Yasmi, Y., Lissa, K., \& Thomas, E. (2011). The Forest conflict in Asia and the role of collective action in its 
management, Capri Working Paper, December 2011

Yuhana, Cement Manufacturers, Wulan. Yurdi Yasmi and Ancient Christian. (2004). Forest Conflict in Indonesia Before and After Reform. CIFOR (Centre for International Forestry Research): Policy Gazette No.15 of 2004.

\section{Copyrights}

Copyright for this article is retained by the author(s), with first publication rights granted to the journal.

This is an open-access article distributed under the terms and conditions of the Creative Commons Attribution license (http://creativecommons.org/licenses/by/3.0/). 